\title{
The Effective Mechanisms in Monitoring and Management of E-Government
}

\author{
Rasim Alguliyev \\ Department of Information Society problems \\ Institute of Information Technology of ANAS \\ 9, B.Vahabzade str., AZ1141, Baku, Azerbaijan \\ E-mail: rasim@science.az \\ Farhad Yusifov (Corresponding author) \\ Department of Information Society problems \\ Institute of Information Technology of ANAS \\ 9, B.Vahabzade str., AZ1141, Baku, Azerbaijan \\ farhadyusifov@gmail.com
}

Accepted: April 27, 2015

Doi:10.5296/ jpag.v5i2.7405 URL: http://dx.doi.org/10.5296/ jpag.v5i2.7405

\begin{abstract}
In paper main principles of formation and management of e-government are analyzed. Web analytics application issue is investigated as the possibility to increase the effectiveness of e-government management indicators. Web analytics is analyzed as effective feedback mechanism in monitoring and management of e-government. Some recommendations on how to design e-government programs were made.
\end{abstract}

Keywords: E-government, web analytics, public administration 


\section{Introduction}

Currently, different projects related to formation of electronic government (e-government) are developed and carried out worldwide. Increasing of electronic readiness and acceleration of e-government development during the past few years can be indicated as the most noticeable tendencies in direction of information society formation. Regular monitoring of these tendencies are the main focus points of many international and national organizations (UN EGS 2010, 2010; UN EGS 2014, 2014; MIS 2010, 2010; GITR 2009-2010, 2010).

United Nations (UN) regularly publishes analytical reports on e-government application practice and use in different countries in the world (UN EGS 2010, 2010; UN EGS 2014, 2014). E-government survey 2014 covered 193 countries. It serves to identify their areas of strength and challenges in e-government and to guide e-government strategies. Due to a number of factors, there are digital divide among regions and countries in their state of e-government development as observed throughout the 2014 Survey. The 2014 Survey also examined the specific challenges and development of e-government in the following three country groups: the Least Developed Countries, Small Island Developing States and Land-Locked Developing Countries (UN EGS 2014, 2014). The effective approaches as well as the comparative advantage of the whole-of-government approach should be considered in forming the future strategies for e-government.

Objectives of e-government can included: provision of transparence of government authorities operations, provision of information freedom, increasing effectiveness of government authorities, close participation of citizens (regardless of physical capabilities) in government structures, rendering government services in online environment, provision of security etc. In different countries, and primarily USA and Great Britain, generally, e-government is considered as a concept which can be directed at improving of public administration activity. In the other words, the essence of e-government consists of direct provision of information and services by different levels of government structures to consumers using modern information technologies. Citizens, non-government organization or government structures are consumers of e-government services and simultaneously their voice can influence decisions of government (mainly in the countries with high e-participation).

While reviewing e-government programs conducted in different countries worldwide, it is clear that shortly, in near future e-government will become more citizen-centering, transparency, accessible and more effective with using "one window" principle (Misuraca, Broster, \& Centeno, 2012; Wenhua, \& Jian, 2010; De, 2008). This is mostly depends on rapid development of ICT and web technologies. From this point, the use of effective management mechanisms in realization of e-government projects is a quite an important issue.

Web-analytics used for improvement of e-government management indicators and creation of feedback mechanism (Alguliev, \& Yusifov, 2013; Kaushik, 2010; Traunmüller, \& Leitner, 2008). Note that, if effective administration policy is the most important issue of implementation of e-government programs, then, applying new applications can significantly broadened the political communication capabilities. In its turn, information based on 
web-analytics allows new integration ways between government, business sector and citizens Alguliev, \& Yusifov, 2013).

\section{Public Administration Concept and Monitoring of E-Government}

Regardless of government formation characteristics and economy development level, in any modern country the government is the main provider of services for citizens and business sector. Government institutions are the source of normative acts. They license different activity fields, provide population's social security and implement a number of other necessary social functions. Moreover, private and government organizations act as the largest product and service consumers.

The essence of e-government management is in incessant optimization of rendered services, provision of participation of citizens in management thanks to rebuilding of external and internal relations using ICT. Thus ICT acts here only as a tool for reaching the main goal optimization of rendered governmental services. So namely administrational reforms must form the basis of relevant changes (Misuraca, Broster, \& Centeno, 2012; De, 2008; Alguliev, \& Yusifov, 2013; Traunmüller, \& Leitner, 2008).

A number of issues of technical, administrative, and legal nature must be solved in order to implement the e-government program. Among these is preparation of inter-institution mutual relation regulations, development of classification of governmental services, as well as realization of architecture and software-hardware platform.

Thus, e-government is not a provision measure, but a public administration concept. Changes in formation principals of normative-legal basis, budgetary incomes and expenses, assignment of legitimate statuses to e-documents and regulations are important measures for conduction of public administration reforms and successful activity of e-government.

Application of web analytics allows improving e-government management mechanisms by centralized administration of resources belonging to e-government, monitoring of web sites, portals and contents, analysis of number of access, analysis of user and professional forums (Wenhua, \& Jian, 2010; Alguliev, \& Yusifov, 2013; Kaushik, 2010).

Note that, administrators must use the ICT tools, as well as web analytics in order to achieve improvement and transparency of governmental funds' usage, and increase of the effectiveness of governmental services. Government sector services must provide implementation of transparent and accessible decisions, must be interactive and in online mode. ICT tools must be applied in such a manner that will form policy more accountable and allow a higher level of monitoring, evaluation and control (UN EGS 2014, 2014; Wenhua, \& Jian, 2010; Alguliev, \& Yusifov, 2013; Whitmore, 2012).

E-government monitoring system includes proposals which are given below:

- e-government indicators must be formed with consideration of interactivity level of the online public services;

- indicators must be formed in relevance with management level; 
- indicators must be edited in case of change in e-government development and conditions;

- indicators related to interactivity level, service quality must be used etc.

Indicator list on e-government management and realization level includes the points which are given below: number of services rendered in online mode, quality of these services and availability of application for such services.

Another important aspect of e-government management is definition of what information to collect, from what sources, and what effective analytical methods to use. Generally, information sources may be Web-sites and IT-bodies of governmental institutions, users citizens, organization or governmental officials.

In this case, in principle, analysis of web-sites and portals content provides more reliable information. Two methods can be used for this: Investigation of sites by administrators (experts) who analyze the sites and provide their opinion; identification the patterns of user behavior and interests.

\section{Web Analytics as Effective Mechanism of E-Government}

Effective web-analysis - is detailed analysis of behavior and user profiles on web-site. It is impossible to take measures on optimization of web-sites without knowledge on exact behavior of users on the site. Analyzing and optimization of web resources is an important issue for adaptation of the site to requirements of citizens (Alguliev, \& Yusifov, 2013; Kaushik, 2010).

Web analytics of web-sites of public authorities, as well as sites rendering online services to citizens - is detection of technical and content directed errors and adaptation of the sites to requirements of citizens and users. Using web analytics allows clarifying the reasons why users leave web sites, actions and behavior of users on sites or web-pages related to specific services (Liu, \& Keselj, 2007; Everts, \& Bulacu, 2005; Wanga, Abraham, \& Smitha, 2005).

Note that, web analytics is not limited only with statistics and also allows to obtain more detailed information for analysis (Alguliev, \& Yusifov, 2013; Wanga, Abraham, \& Smitha, 2005; Balog, Hofgesang, \& Kowalczyk, 2005; Smith, \& Ng, 2003; Qiu, \& Cho, 2006).

Analyzing of web-traffic and log-files allows to understand (Alguliev, \& Yusifov, 2013; Everts, \& Bulacu, 2005; Wanga, Abraham, \& Smitha, 2005; Cooley, 2003).

- User behavior and profile,

- Number of visited web-pages,

- Keywords and phrases which visitors use,

- Geography of visitors,

- Time and activity, spent on the web-page by visitor,

- Path between web-pages, 
- Audience of the site (accidental, permanent visitors etc.)

- Site navigation and etc.

Considering international experience, the state programs actions plan is proposed to implement in the Republic of Azerbaijan in two steps with the for conduction of e-government program. The need to prepare such a concept is due to the fact that Azerbaijan has stepped into a new stage of development. The achievements that have been gained allow Azerbaijan to set even higher goals and determine the tasks that stem from these goals (Azerbaijan 2020, 2012).

On the lower step, field action plans (for example e-ministry, e-district, e-municipality etc.) are prepared for different central, local executive power, court, and legislation and municipality institutions. On higher step, countrywide main action plan is prepared. In field action plans, ICT projects on countrywide level of relevant administration institutions and administrative-territorial division of local executive and municipal institutions are carried out. ICT application action plan in education system, scientific action plan, customs service's action plan etc. can be listed as examples. By conducting this conceptual approach, duties and responsibilities of each governmental institution in ICT field will be clear, digital divide occurring as a result of application of ICT in government sector will be reduced to minimum, conduction of monitoring will be simplified, process management can be conducted on a high level, more effective main action plans can be prepared in future by conducting comparative analysis (Azerbaijan 2020, 2012). In its turn, this will allow to create bases for evaluation of e-government formation and development (dynamics), processing of indicators on field and administrative territorial divisions, and creation of monitoring system based on these.

Noted that, decision making in online environment, studying social opinion, conduction of referendums and elections, processing of technologies as well as creation of situation center for each institutions included in e-government are quite important issues (Alguliev, \& Yusifov, 2013). Considering that such situation centers are created based on supercomputers, development of mutual relations among them relevant to security policy requirements can be one of the important set forth duties. Analysis of log files and information collected in e-mails during the process of development of on-line relations among citizens and government institutions play an important role in effective decision making by e-government subjects as a result of web analysis usage.

For the provision of citizen access to public authorities countrywide, the forming of social Internet centres and points infrastructure in settlements is one of the impotant issues on forming e-government. So that, e-government must perform sustainably, be reliable and secured against threats. Namely, information, energy and etc. security of e-government must be provided and be prepared for information war.

In its turn, it allows to process feedback mechanisms for e-government management. Formation of public Internet centers and points in residential areas in order to provide the access of citizens' country wide to e-government institutions is one of the important issues in e-government. 
According to the concept of e-government, the whole system of public authorities performs as an integral service organization for the provision of services to citizens. The performance of e-government must be clear, transparent and available in terms of information for citizens. The specific attention is drawn to establishment of feedback mechanism, efficiency of services provision and execution period by using the centralized systems. All above listed items enable to increase either the quality of provision of services provided by the government to citizens, or the performance efficiency of government.

\section{Conclusion}

Development of e-government is the primary direction of development of the Republic of Azerbaijan. As it's clear from conducted research, e-government development monitoring cannot be limited to accessibility of ICT and its usage indicators. Factors significantly affecting e-government development must be continuously controlled, analyzed and evaluated by the government. Use of web analytics in e-government management is one possibility of feedback mechanisms and a strong tool in effective decision making.

\section{Acknowledgement}

This work was supported by the Science Development Foundation under the President of the Republic of Azerbaijan - Grant № EİF/GAM-2-2013-2(8)-25/03/1

\section{References}

"Azerbaijan 2020: Look Into The Future" concept of development (Azerbaijan 2020), (2012). Retrieved from www.president.az

Alguliev, R., \& Yusifov, F. (2013). Effective E-government Management Mechanisms: Conceptual Approaches, Universal Journal of Communications and Network, vol. 1(2), pp. 44-49

Balog, K., Hofgesang, P.I., \& Kowalczyk, W. (2005). Modeling Navigation Patterns of Visitors of Unstructured Websites. In: Proccedings of the Twenty-fifth SGAI International Conference on Innovative Techniques and Applications of Artificial Intelligence. Springer Verlag. Retrieved from www.cs.vu.nl

Cooley, R. (2003). The Use of Web Structure and Content to Identify Subjectively Interesting Web Usage Patterns. In: ACM Transactions on Internet Technology, vol. 3, no 2, p. 93-116

De', R. (2008). Electronic governance theory. In: ICEGOV'2008, pp. 11-15

Everts, J., \& Bulacu, M. (2005), Assignment: Clustering of Web Users. Groningen University, Netherlands. Retrieved from www.ai.rug.nl

Kaushik, A. (2010). Web Analytics 2.0 - The Art of Online Accountability and Science of Customer Centricity, Wiley Publishing, Inc. 447 p.

Liu, H., \& Keselj, V. (2007). Combined mining of web server logs and web contents for 


\section{Macrothink}

Journal of Public Administration and Governance ISSN 2161-7104 2015, Vol. 5, No. 2

classifying user navigation patterns and predicting users' future requests. In: Data and Knowledge Engineering, vol. 61, no 2, p. 304-330

Measuring the Information Society 2010 (MIS 2010). (2010). Retrieved from www.itu.int

Misuraca, G., Broster, D., \& Centeno, C. (2012). Digital Europe 2030: Designing scenarios for ICT in future governance and policy making. Journal of Government Information Quarterly, vol. 29, pp. 121-131

Qiu, F., \& Cho, J. (2006). Automatic identification of user interest for personalized search. In: Proccedings of the 15th WWW Conference (WWW15), Edinburgh, Scotland, pp. 727-736

Smith, K., \& Ng, A. (2003). Web page clustering using a self-organizing map of user navigation patterns. In: Decision Support Systems, vol.35, No 2, p. 245-256

The Global Information Technology Report 2009-2010 (GITR 2009-2010). (2010). Retrieved from www.weforum.org

Traunmüller, R., \& Leitner, C. (2008). e-Government: State and Perspectives. In: ICEGOV'2008, pp. 4-7

UN E-Government Survey 2014 (UN EGS 2014). (2014). Retrieved from http://unpan3.un.org

United Nations E-Government Survey 2010 (UN EGS 2010). (2010). Retrieved from www2.unpan.org

Wanga, X., Abraham, A., \& Smitha, K.A. (2005). Intelligent web traffic mining and analysis. In: Journal of Network and Computer Applications, vol. 28, p.147-165

Wenhua, X., \& Jian, Y. (2010). E-government and the change of government management mode. In: International Conference on E-Business and E-Government, pp. 675 - 678

Whitmore, A. (2012). A statistical analysis of the construction of the United Nations E-Government Development Index. Journal of Government Information Quarterly, vol. 29, pp.68-75, Retrieved from www.elsevier.com

\section{Copyright Disclaimer}

Copyright reserved by the author(s).

This article is an open-access article distributed under the terms and conditions of the Creative Commons Attribution license (http://creativecommons.org/licenses/by/3.0/). 